\title{
Diskursus Hukum: Alternatif Pola Pengisian J abatan Kepala Daerah di Masa Pandemi Covid-19
}

\author{
Richard Kennedy1*, Bonaventura Pradana Suhendarto² \\ IFakultas Hukum dan Komunikasi, Universitas Katolik Soegijapranata Semarang \\ 2Program Studi Magister IImu Hukum, Fakultas Hukum, Universitas Diponegoro \\ *kenrichi27@gmail.com
}

\begin{abstract}
Covid-19 pandemic caused the 2020 elections to be rescheduled. The government together with KPU and DPR agreed to postpone the 2020 elections until December 2020, through Perppu No. 2 of 2020. Unfortunately, the condition of covid-19 in Indonesia has yet to show of ending. Consequently, the 2020 elections have the potential to be rescheduled again and are in uncertainty. Position of regional leader in some areas has the potential to experience emptiness. In fact, the role of regional leaders in the handling of the covid-19 pandemic is vital. Therefore, this paper would like to provide an alternative pattern of filling the position of regional leader during the covid-19 pandemic. There are 3 patterns proposed namely the appointment of a temporary official or implementer, indirect local elections, and local elections using an electronic system. These patterns have their advantages and disadvantages, accompanied by strong legal and juridical arguments. But, the Government through Perppu No. 2 of 2020 is more willing to hold conventional direct elections. Therefore, the final part of this paper tries to discuss the law to guarantee the implementation of the elections in the covid-19 pandemic by paying attention to the application of strict health protocols.
\end{abstract}

Keywords: Covid-19; Democracy; Discourse; Law; Local Elections.

\begin{abstract}
ABSTRAK
Pandemi covid-19 menyebabkan Pilkada 2020 mengalami penjadwalan ulang. Pemerintah bersama KPU dan DPR sepakat menunda Pilkada 2020 hingga bulan Desember 2020, melalui Perppu No. 2 Tahun 2020. Sayangnya, kondisi covid-19 di Indonesia hingga kini belum menunjukan tanda-tanda akan berakhir. Konsekuensinya, Pilkada 2020 berpotensi kembali dijadwalkan ulang dan berada pada ketidakpastian. Jabatan kepala daerah di beberapa wilayah berpotensi mengalami kekosongan. Padahal, peran kepala daerah dalam penanggulangan pandemi covid-19 cukup vital. Karenanya, artikel ini hendak memberikan alternatif pola pengisian jabatan kepala daerah di masa pandemi covid-19. Ada 3 usulan pola yang diajukan, yaitu penunjukan Penjabat sementara atau Pelaksana Tugas, Pilkada tidak langsung, dan Pilkada menggunakan sistem elektronik. Ketiga pola alternatif ini memiliki kelebihan dan kekurangannya masingmasing, dengan disertai argumentasi yuridis dan logis yang kuat. Namun sepertinya, Pemerintah melalui Perppu No. 2 Tahun 2020 lebih berkeinginan untuk menyelenggarakan Pilkada langsung secara konvensional. Karenanya, bagian akhir artikel ini mencoba mendiskursuskan hukum untuk menjamin pelaksanaan Pilkada ditengah pandemi covid-19 dengan memperhatikan penerapan protokol kesehatan yang ketat.
\end{abstract}

Kata Kunci: Covid-19; Demokrasi; Diskursus; Hukum; Pilkada. 


\section{A. PENDAhUluan}

Corona Virus Disease 2019 (Covid-19) saat ini tengah melanda berbagai negara di belahan dunia. Transmisi virus ini terjadi antar manusia secara meluas dan cepat (Susilo et. al, 2020). Manusia mendapatkan ancaman serius karenanya, termasuk organisasi super power sekelas negara. Covid-19 tak hanya mempengaruhi aspek kesehatan, melainkan menembus pula kehidupan sosial, perekonomian, hingga pemerintahan (Gennaro et.al., 2020). Organisasi Kesehatan Dunia (WHO) bahkan telah mengumumkan Covid-19 sebagai pandemi global sejak 11 Maret 2020 (World Health Organization, 2020).

Berbagai negara melakukan kebijakan pembatasan berskala besar. Agenda internasional ataupun nasional ikut terdampak. Olimpiade Tokyo 2020 misalnya, yang harus ditunda karena alasan pandemi. Belum lagi agenda kenegaraan lain yang sifatnya fundamental, seperti pemilihan umum (Pemilu) atau referendum nasional. Tercatat, 55 negara menunda pemilu nasional ataupun lokal dan referendum nasional. Namun, ada 21 negara yang tidak menunda pemilu, 9 diantaranya telah terselenggara di tengah pandemi Covid-19. Korea Selatan menjadi salah satu negara yang berhasil menyelenggarakan pemilu pada 15 April 2020 (International Institute for Democracy and Electoral Assistance, 2020).

Sedangkan Indonesia menjadi 1 dari 55 negara yang memilih untuk menunda pelaksanaan pemilu lokal. Sedianya, berdasarkan Pasal 201 ayat (6) UU No. 10 Tahun 2016, Indonesia memiliki agenda untuk menyelenggarakan Pemilihan Umum Kepala Daerah (Pilkada) di tanggal 23 September 2020. Namun, melalui Peraturan Pemerintah Pengganti Undang-Undang (Perppu) No. 2 Tahun 2020, Pemerintah Indonesia memutuskan untuk menjadwalkan ulang pilkada menjadi tanggal 9 Desember 2020. Keputusan ini menimbulkan perdebatan di masyarakat, terutama di kalangan akademisi. Penjadwalan pilkada di bulan Desember 2020 dinilai tak realistis. Karena faktanya, hingga 16 Mei 2020 jumlah kasus positif Covid-19 terus meningkat secara nasional (Ramadhan, 2020). Banyak pihak khawatir, bila pilkada tetap dilangsungkan Desember 2020 justru akan menjadi klaster baru penyebaran Covid-19.

Perppu No. 2 Tahun 2020 mengatur 3 perubahan mendasar, yaitu: (1) Pasal 120 yang menyatakan faktor bencana non-alam sebagai alasan penundaan rangkaian pilkada; (2) Pasal 122A berkaitan dengan penundaan dan penetapan pilkada lanjutan ditetapkan berdasarkan kesepakatan Komisi Pemilihan Umum (KPU), Pemerintah, dan Dewan Perwakilan Rakyat Republik Indonesia (DPR RI); (3) berdasarkan Pasal 201A, Pilkada yang semula dijadwalkan pada September 2020 ditunda dan dilaksanakan pada bulan Desember 2020 karena alasan bencana non-alam pandemi Covid-19, bila pada bulan Desember 2020 pilkada belum dapat 
Jurnal Pembangunan Hukum Indonesia

Volume 2, Nomor 2, Tahun 2020
Program Studi Magister Ilmu Hukum

Fakultas Hukum Universitas Diponegoro dilaksanakan, maka dapat ditunda kembali sesuai prosedur Pasal 122A.

Pasal 201A Perppu tersebut merupakan kebijakan hukum terbuka (open legal policy), yang memungkinkan adanya penundaan pilkada lanjutan bila kondisi pandemi Covid-19 belum mereda. Hal ini dapat dilakukan berdasarkan kesepakatan KPU, Pemerintah, dan DPR yang dituangkan dalam Penetapan KPU. Untuk pelaksanaan pilkada lanjutan harus diatur dalam peraturan KPU. Namun sayangnya, kondisi Covid-19 yang tidak terprediksikan membuat pelaksanaan pilkada 2020 berada pada ketidakpastian. Konsekuensi logisnya, akan menimbulkan kekosongan jabatan kepala daerah. Padahal, faktor kepemimpinan lokal memiliki pengaruh dalam efektivitas pengendalian pandemi Covid-19 (Yang, \& Ren, 2020).

Menurut catatan sejarah, Aceh dan Yogyakarta pernah mengalami penundaan pilkada akibat bencana alam. Namun, Indonesia baru kali ini mengalami penundaan pilkada akibat pandemi yang penyebarannya meluas. Karena itu, artikel ini akan mengusulkan dan membahas berbagai alternatif pola pengisian jabatan kepala daerah di tengah pandemi Covid-19. Alternatif pola yang diusulkan meliputi pola pengisian jabatan melalui penunjukkan pelaksana tugas atau penjabat sementara, pilkada tidak langsung, dan pilkada menggunakan media elektronik.

Selain itu, artikel ini akan mendiskursuskan aturan terkait pelaksanaan pilkada di tengah pandemi Covid-19. Kondisi normal baru (new normal) membuat manusia harus beradaptasi dengan keadaan, termasuk ketika hendak menjalankan pilkada. Korea Selatan patut dijadikan contoh ketika berhasil menyelenggarakan pemilu di tengah pandemi Covid-19. Korea Selatan melakukan sosialisasi yang masif serta memperhatikan dan menerapkan protokol kesehatan secara ketat dalam penyelenggaraan pemilu.

Sebagaimana kita ketahui, pemilu adalah konsekuensi logis dari negara demokrasi, dan demokrasi adalah cara aman untuk mempertahankan kontrol atas negara hukum (Hidayat, 2010). Pasal 1 ayat (2) dan ayat (3) UUD 1945 menyatakan bahwa Indonesia adalah negara hukum yang demokratis. Demokrasi, negara hukum, dan negara kesejahteraan menjadi dasar filosofis dari penyelenggaraan pemilu (Nugraha, 2018). Pemilu yang demokratis bagi Satjipto Rahardjo ialah lembaga yang mereproduksi kontrak sosial baru antara rakyat dengan pemimpin pemerintahan (Budhiati, 2013). Pemilu yang demokratis, dapat dijalankan secara langsung maupun tidak langsung (Melfa, 2013). Menurut Jimly Asshiddiqie, selain sebagai perwujudan demokrasi dan Hak Asasi Manusia (HAM), pemilu bertujuan untuk mengisi dan melaksanakan suksesi kepemimpinan secara tertib (Asshiddiqie, 2014).

Indonesia, berdasarkan UUD 1945 menempatkan pilkada pada tata hukum yang berbeda dengan tata hukum pemilu. Pasal 22E UUD 1945 menentukan pemilu dilaksanakan untuk memilih Presiden dan Wakil Presiden, anggota DPR 
RI, anggota Dewan Perwakilan Daerah (DPD), serta anggota Dewan Perwakilan Rakyat Daerah (DPRD). Sedangkan, Pasal 18 UUD 1945 hanya menyatakan bila Pilkada dilaksanakan secara demokratis. Frasa "secara demokratis" inilah yang sering menjadi perdebatan di kalangan pakar hukum tata negara, mengenai pola pilkada langsung atau tidak langsung yang seharusnya diterapkan di Indonesia. Selain itu, perkembangan revolusi industri 4.0 juga membawa perkembangan baru untuk mendiskusikan pemilu dengan menggunakan media elektronik (Sobari, 2019). Tentu pola-pola ini dirasa perlu untuk didiskusikan kembali di saat pandemi seperti ini.

Pandemi Covid-19 memaksa kita untuk membuat norma dan normal baru (memperbarui kebiasaan, tingkah laku, dan berbagai aturan). Demokrasi tetap harus dijalankan, namun dengan mematuhi dan menjaga protokol serta hak kesehatan masyarakat. Hak kesehatan adalah HAM, yang muncul karena demokratisasi (Aswandi, \& Roisah, 2019), maka rasanya kurang elok bila hak kesehatan dikorbankan atas nama demokrasi. Pilkada tidak terbatas pada persoalan pemungutan suara, namun terdiri dari beberapa rangkaian mulai dari pendaftaran calon, verifikasi data lapangan, kampanye, dIl yang berpotensi menimbulkan kerumunan masa. Kita memerlukan pembentukan dan pembaharuan pengetahuan hukum yang didasarkan secara kritis untuk mengubah praktik Pilkada di Indonesia (diskursus hukum mengenai pilkada) (Danardono, 2016). Demokrasi yang berkultur Indonesia haruslah kita gali (Anwar, 2011) untuk menunjukkan jati diri kita sebagai bangsa Indonesia. Menurut Satjipto Rahardjo, kita masih perlu mendiskursuskan dan terus membangun Indonesia dengan cita-cita menjadikan Indonesia sebagai negara hukum yang membahagiakan rakyatnya (Rahardjo, 2009).

Sejauh ini, penelitian terkait Pilkada di Indonesia masih berfokus pada perdebatan pola pilkada langsung atau tidak langsung, yang hasilnya bermuara pada tafsir Pasal 18 ayat (4) UUD 1945 dan keunggulan serta kelemahan masing - masing pola (Respationo,2013). Fenomena calon per seorangan dalam pilkada juga pernah dibahas, hasilnya menunjukkan masih adanya problematika mengenai calon perseorangan (Santoso, 2017). Hasil penelitian lainnya menunjukkan fenomena calon perseorangan memunculkan perspektif dan tatanan baru pilkada di Indonesia (Saraswati, 2011). Ada pula penelitian lain menunjukkan fenomena dukungan kotak kosong sebagai gerakan masyarakat madani yang bebas (Widyasari, Dewi, \& Rengganis, 2019).

Sayangnya, penelitian mengenai Pilkada di tengah bencana ataupun pandemi masih belum pernah di bahas, kendati Indonesia pernah mengalaminya untuk daerah Yogyakarta dan Aceh. Penelitian internasional hanya menunjukan tantangan dalam menyelenggarakan pemilu di tengah pandemi covid-19 (Landman, \& Splendore, 2020). Ada sebuah penelitian di Jerman yang menunjukkan perilaku politik dan situasi pemilu di negara bagian Bavaria, Jerman, ketika pandemi terjadi (Leininger, \& Schaub, 2020), namun untuk 
pengalaman Pemilu Korea Selatan di tengah pandemi justru belum ditemukan sama sekali dalam dokumen penelitian manapun dan hanya ada dalam pemberitaan media. Karena itu, artikel ini akan ambil bagian untuk membicarakan diskursus hukum dan alternatif pola pengisian jabatan kepala daerah di Indonesia saat masa pandemi Covid-19.

Berdasarkan latar belakang di atas, maka rumusan masalah utama dalam artikel ini ialah: "Bagaimana diskursus hukum mampu memberikan alternatif pola pengisian jabatan kepala daerah di tengah pandemi Covid-19?". Untuk mempermudah analisa dan pembahasan, artikel ini akan dibagi dalam 2 sub, yaitu: (1) Alternatif Pola Pengisian Jabatan Kepala Daerah di Tengah Pandemi Covid19; dan (2) Diskursus Hukum Pemilihan Kepala Daerah di tengah Pandemi Covid-19.

\section{B. PEMBAHASAN}

\section{Alternatif Pola Pengisian Jabatan Kepala Daerah di tengah Pandemi Covid-19}

Konsekuensi logis penundaan pilkada ialah terjadi kekosongan jabatan kepala daerah di sejumlah wilayah. Kekosongan jabatan kepala daerah tentu tidak dapat dibiarkan begitu saja. Perlu solusi untuk mengisi kekosongan tersebut demi menjamin berjalannya roda pemerintahan daerah serta pengembangan daerah tersebut. Berikut alternatif solusi yang dapat dilakukan :

\section{a. Penunjukkan Pelaksana Tugas}

Penunjukkan pelaksana tugas (PIt) menjadi alternatif solusi untuk mengisi kekosongan jabatan tersebut. Alternatif ini sering dilakukan belakangan terlebih dalam rangka menciptakan pilkada serentak di sejumlah daerah di Indonesia. Penunjukkan pelaksana tugas untuk mengisi kekosongan jabatan kepala daerah bersangkutan berasal dari jabatan pimpinan tinggi madya untuk jabatan Gubernur berdasarkan Pasal 201 ayat (8) UU No. 8 Tahun 2015 dan jabatan pimpinan tinggi pratama untuk jabatan Bupati/ Walikota berdasarkan Pasal 201 UU No. 8 Tahun 2015.

Sistem ini sebenarnya pernah dilakukan dalam sejarah pilkada di Indonesia. UU No. 1 Tahun 1945 tentang Kedudukan Komite Nasional Daerah memberikan mandat kepada pemerintah pusat untuk memilih dan mengangkat kepala daerah. Begitu pula dengan UU No. 22 Tahun 1948 tentang Penetapan Aturan-Aturan Pokok Mengenai Pemerintah Sendiri di Daerah-Daerah Berhak Mengatur dan Mengurus Rumah Tangganya Sendiri maupun UU No. 5 Tahun 1974 tentang Pokok-Pokok Pemerintahan Daerah memberikan mandat kepada DPRD untuk mengusulkan beberapa calon kepala daerah kepada pemerintah pusat untuk dipilih dan diangkat menjadi kepala daerah tetap (Hutapea, 2015).

Penunjukkan pelaksana tugas oleh Menteri Dalam Negeri (Mendagri) saat ini serupa dengan sistem pilkada yang pernah dilakukan Indonesia meskipun pada waktu itu subjek yang dipilih adalah untuk menjadi kepala daerah tetap. Pelaksana tugas mengisi kekosongan jabatan kepala daerah hingga pelantikan kepala daerah tetap hasil pilkada serentak. 
Pelaksana tugas hanya memiliki kewenangan yang terbatas menurut Pasal 132A PP No. 49 Tahun 2008 dan tidak berwenang mengambil keputusan maupun kebijakan strategis. Kekuatan politik pelaksana tugas pun dinilai lemah jika dibandingkan dengan pejabat lainnya yang memiliki jabatan lebih tinggi. Oleh karena itu meskipun terdapat pelaksana tugas dalam suatu daerah, roda pemerintahan daerah serta perkembangan daerah akan terganggu (Deliarnoor, 2015). Terlebih bila kekosongan jabatan kepala daerah tersebut terjadi hingga waktu yang cukup lama. Hal itu dikarenakan pilkada serentak yang ditunda menjadi bulan Desember 2020 masih sangat mungkin ditunda kembali pada tahun 2021 apabila dampak pandemi Covid-19 belum mereda.

Permasalahan lain yang muncul adalah amanat UU Pilkada, dengan mencanangkan rencana besar pilkada serentak secara nasional pada tahun 2027. Tentu ditundanya pilkada serentak tahun 2020 ini mengganggu rencana besar tersebut. Pada akhirnya akan menimbulkan jangka waktu jabatan kepala daerah yang lamanya tidak mencapai 5 tahun di beberapa daerah. Berdasarkan Pasal 202 UU No. 8 Tahun 2015, meskipun kepala daerah menjabat tidak sampai 5 tahun akan tetap dihitung sebagai 1 periode. Sehingga kepala daerah tersebut tetap mendapatkan kompensasi sebesar gaji pokok dikalikan jumlah bulan yang tersisa serta mendapat hak pensiun untuk 1 periode.

Secara prosedural mungkin tidak menimbulkan permasalahan yang cukup signifikan, akan tetapi secara politis tentu berpengaruh dan tetap menimbulkan kerugian. Kepala daerah terpilih yang tidak dapat menjalankan jabatannya selama 5 tahun hanya akan mendapat kompensasi gaji pokok dan hak pensiun saja, sedangkan jika yang bersangkutan menjabat selama 5 tahun akan mendapatkan berbagai tunjangan yang nilainya cukup besar pula. Jika dikalkulasikan tidak sebanding dengan biaya kampanye yang masih cukup besar.

Selain itu, kewenangan politik yang seharusnya dapat dimiliki selama 5 tahun menjadi berkurang hanya selama menjabat saja. Padahal kewenangan politik inilah yang berpengaruh untuk mewujudkan misi kepala daerah yang pernah disampaikan ketika kampanye. Tidak mungkin seorang kepala daerah hanya memiliki rencana strategis pengembangan daerah yang dicanangkan ketika kampanye hanya untuk beberapa tahun saja, sudah pasti akan mencanangkan untuk 5 tahun. Lagipula setiap kepala daerah tidak ingin dianggap gagal oleh masyarakatnya karena tidak dapat maksimal dalam menjalankan program visi misinya hanya karena keterbatasan waktu menjabat. Setidaknya itulah beberapa persoalan baik dari sisi roda pemerintahannya maupun kepala daerah terpilih nantinya jika ditunjuk pelaksana tugas untuk mengisi kekosongan kepala daerah.

\section{b. Pemilihan Kepala Daerah Secara Tidak Langsung}

Pilkada tidak langsung merupakan sistem pemilihan kepala daerah yang dipilih oleh DPRD atau yang dikenal dengan sistem perwakilan (Hutapea, 2015). Sistem ini bukanlah pola baru, tetapi pernah 
Jurnal Pembangunan Hukum Indonesia

Volume 2, Nomor 2, Tahun 2020
Program Studi Magister Ilmu Hukum

Fakultas Hukum Universitas Diponegoro digunakan dalam sejarah perkembangan pilkada di Indonesia. Sebut saja dengan UU No. 1 Tahun 1957 tentang Pokok-Pokok Pemerintah Daerah, UU No. 18 Tahun 1965 tentang Pokok-Pokok Pemerintahan Daerah, dan UU No. 22 Tahun 1999 tentang Pemerintah Daerah menggunakan mekanisme keterwakilan DPRD sebagai pemilih kepala daerah. (Saraswati, 2011)

Sistem tersebut sempat dicanangkan kembali dengan UU No. 22 Tahun 2014 tentang Pemilihan Gubernur, Bupati, dan Walikota, namun karena mendapat desakan politis dari berbagai kalangan pada akhirnya tidak jadi digunakan sebagai mekanisme pemilihan kepala daerah saat itu. Perppu No. 1 Tahun 2014 langsung diterbitkan dan dijadikan undang-undang untuk mengembalikan sistem pilkada secara langsung oleh rakyat.

Masyarakat masih menilai pilkada tidak langsung sebagai sistem yang kurang demokratis. Pasal 18 ayat (4) UUD 1945 menyatakan bahwa kepala daerah dipilih secara demokratis. Frasa kata "demokratis" inilah yang sering diartikan sempit sebagai pemilihan langsung oleh rakyat, padahal UUD 1945 sendiri tidak mengharuskan kepala daerah dipilih langsung.

Hal ini senada dengan pendapat Jimly Asshiddiqie dan Mahfud MD yang menyatakan bahwa pilkada secara langsung oleh rakyat maupun tidak langsung dengan melalui DPRD, keduanya haruslah diartikan sebagai pemilihan yang samasama demokratisnya. Sehingga keduanya pun dipandang konstitusional (Hardjaloka, 2015). Secara historis amandemen pasal 18 ayat (4) UUD 1945 pun mengindahkan gagasan otonomi daerah dan keragaman daerah dengan sistem pemilihan secara adat istiadat tertentu, sehingga disebutlah frasa kata "demokratis" sebagai jalan keluar.

Sejalan dengan itu, Bagir Manan pun berpendapat bahwa pasal amandemen tersebut telah sesuai dengan semangat mewujudkan pembentukan pemerintahan daerah yang mandiri dan demokratis. Sehingga pilkada pun merupakan bagian dari kewenangan pemerintah daerah untuk menyelenggarakan sesuai adat istiadat maupun asal usul daerah tersebut. Kemudian apabila dicermati, ketentuan pasal tersebut merupakan rezim pemerintah daerah, sebab pembahasan dan rumusannya berada di luar Pasal 22E UUD 1945 yang merupakan dasar konstitusional pemilu (Sodikin, 2015). Oleh karenanya, ketentuan tersebut perlu dipahami secara luas dan bukan sekedar pemahaman sempit.

Lagipula saat ini DPRD memiliki kewenangan untuk memilih wakil kepala daerah dalam hal terjadi kekosongan jabatan wakil kepala daerah. Secara logika, hal ini mengandung arti bahwa sistem pemilihan melalui wakil rakyat atau DPRD digunakan dan diakui oleh negara, meskipun hanya dalam hal terjadi kekosongan jabatan wakil kepala daerah. Tentu menjadi tidak konsisten jika pilkada tidak langsung dikatakan tidak demokratis, karena kewenangan DPRD pada Pasal 317 dan 366 ayat (1) UU No. 17 Tahun 2014 sama artinya dengan pilkada tidak langsung. 
Demokrasi sesungguhnya merupakan kekuasaan (kratos/ kratein) yang berasal dari rakyat (demos) (Aziz, 2016). Jimly Asshiddiqie lalu mengandaikan bahwa demokrasi sebagai konsep kekuasaan dari, oleh, dan untuk rakyat. Lebih lanjut, Yudi Latif menyatakan bahwa demokrasi yang digunakan oleh Indonesia adalah berdasarkan Pancasila dan UUD 1945. Pada sila ke-4 disebutkan "kerakyatan yang dipimpin oleh hikmat kebijaksanaan dalam permusyawaratan/ perwakilan" dan begitu pula UUD 1945 yang menyebutkan kedaulatan berdasar atas kerakyatan dan permusyawaratan. Maka, sejalan yang ditekankan oleh Soekarno dan Moh. Hatta bahwa demokrasi sesungguhnya memiliki unsur kedaulatan rakyat dan juga permusyawaratan perwakilan (Aziz, 2016).

Sistem keterwakilan oleh DPRD pun sebenarnya merupakan bentuk dari demokrasi. Secara demokratis, rakyat telah memilih secara langsung anggota DPRD untuk menjadi wakil rakyat. Sehingga memiliki makna bahwa DPRD telah mendapatkan mandat langsung dari rakyatnya untuk menjalankan tugas mewakili kepentingan rakyat.

Di tengah situasi pandemi Covid-19 ini (mungkin juga bencana atau kedaruratan yang lain), masih relevan membangun opsi pilkada tidak langsung. Selain karena sistem ini sama-sama demokratisnya sesuai dengan UUD 1945 maupun mendorong dalam rangka pengembangan otonomi daerah, sistem ini memiliki beberapa kelebihan. Sistem ini dinilai lebih efektif dan efisien, sebab cara pemilihannya pun sederhana. Meskipun sederhana, proses yang dilakukan cukup ketat dimana salah satunya ada mekanisme uji publik oleh para pakarl ahli maupun tokoh daerah. Ini semua dilakukan untuk menjamin dan mewujudkan kepala daerah dengan kualitas yang tinggi dan berintegritas.

Kemudian, sistem ini cenderung lebih hemat biaya karena tidak perlu mencetak surat suara kertas banyak dan biaya-biaya logistik maupun operasional yang tinggi. Biaya tinggi yang awalnya untuk pilkada langsung, dapat dialokasikan untuk pengembangan daerah dan dapat digunakan untuk menekan penyebaran Covid-19. Lagi pula imbas pandemi Covid-19 ini akan menciptakan kenormalan hidup baru, dimana aspek kesehatan dan physical distancing pasti akan mempengaruhi. Maka, biaya untuk pilkada secara langsung dengan protokol kesehatan tentu akan menambah pengadaan perangkat penunjang yang jumlahnya besar.

Selain itu, ketepatan waktu pilkada juga dapat dilaksanakan agar tidak terjadi penundaan berlarut yang berpotensi mengganggu roda pemerintahan suatu daerah sehingga berdampak pada laju perkembangan daerah. Inilah setidaknya kelebihan pilkada tidak langsung apabila diterapkan terlebih dengan adanya situasi pandemi ini. Walaupun demikian, tidak dipungkiri pula sistem ini terdapat kelemahan dalam praktik di lapangan seperti yang ditakutkan adanya ketidakjujuran, anggota DPRD yang tidak merepresentasikan rakyat, maupun money politic. Namun, money politic pun sebenarnya lebih mudah diawasi oleh aparat penegak hukum sebab penyebarannya tidak meluas seperti layaknya 
Jurnal Pembangunan Hukum Indonesia

Volume 2, Nomor 2, Tahun 2020
Program Studi Magister Ilmu Hukum

Fakultas Hukum Universitas Diponegoro beberapa kejadian money politic saat pilkada secara langsung yang meluas dan sulit diawasi.

Secara konstitusional, kembali merujuk pada Pasal 18 ayat (4) UUD 1945 yang merupakan kebijakan hukum terbuka, dalam arti membuka peluang pembuat undang-undang untuk menafsirkan lebih lanjut. Saat ini, DPR sebagai pembuat undangundang bersama pemerintah nampaknya telah sepakat dengan penafsiran pilkada secara langsung dipilih oleh rakyat. Hal itu nampak dalam Pasal 1 UU No. 8 Tahun 2015 yang menyatakan bahwa pilkada dilangsungkan secara langsung dan demokratis. Maka apabila ingin menggunakan alternatif pilkada tidak langsung, DPR harus melakukan perubahan terhadap UU Pilkada terlebih dahulu agar dapat dilangsungkan pilkada tidak langsung.

\section{c. Pemilihan Kepala Daerah Menggunakan Sistem Elektronik}

Pandemi Covid-19, tidak hanya berdampak negatif. Memang, kita diwajibkan karantina mandiri dan mematuhi segala protokol kesehatan. Namun, dengan terkungkungnya tubuh kita, bukan berarti pikiran kita juga ikut terkungkung. Kita masih dan harus terus membebaskan pikiran dan pemikiran kita. Refleksi, aksi, dan rekreasi, mungkin itu yang akan mewarnai bagian ini. Pola pemilihan secara elektronik mungkin dapat menjadi solusi lain, ketika pola Pilkada tidak langsung ditolak. Sistem Pemilu elektronik memungkinkan kita untuk menjalankan Pilkada secara langsung di tengah situasi pandemi dengan tetap menjalankan protokol kesehatan.
Perkembangan jaman dan revolusi industri 4.0 telah memberikan kemungkinan itu.

Menurut Alvin Toffler, perkembangan dunia terjadi dalam 3 gelombang era, yakni: era aglikultur (tradisional), era industrial (modern), dan menuju pada era informasi (postmodern). Dalam setiap era, sistem dan perilaku masyarakat pun berubah mengikuti jaman (Herimanto, \& Winarno, 2010). Berdasarkan itu, Klaus Shwab (2016), membagi revolusi industri dalam 4 jaman, yakni: (1) Revolusi 1.0, yang terjadi pada abad ke 18 melalui penemuan mesin uap, sehingga memungkinkan barang dapat diproduksi secara masal; (2) Revolusi 2.0, yang terjadi pada abad ke 19-20 melalui penggunaan listrik, sehingga membuat biaya produksi menjadi lebih terjangkau; (3) Revolusi 3.0, yang terjadi pada sekitar tahun 1970an melalui proses komputerisasi; (4) Revolusi 4.0, yang terjadi pada sekitar tahun 2010 melalui rekayasa intelegensia dan internet of thing sebagai tulang punggung pergerakan dan konektivitas manusia dan mesin.

Revolusi $\quad 4.0$ secara fundamental mengakibatkan berubahnya cara manusia berpikir, hidup, dan berhubungan sosial. Era ini akan mendisrupsi berbagai aktivitas manusia dalam berbagai bidang, tidak hanya dalam bidang teknologi, namun juga bidang yang lain seperti ekonomi, sosial, politik, hukum, hingga kebudayaan (Prasetyo, \& Trisyanti, 2018). Karena, manusia di era revolusi 4.0, hidup pada dunia real dan virtual. Dualisme dunia inilah, membuat manusia tidak hanya berkomunitas di dunia real, namun juga virtual (Demartoto, 2013). 
Jurnal Pembangunan Hukum Indonesia

Volume 2, Nomor 2, Tahun 2020
Program Studi Magister Ilmu Hukum

Fakultas Hukum Universitas Diponegoro
Akibatnya, timbul suatu budaya baru, yaitu budaya siber (cyber culture).

Menurut Michael Heim (1993), budaya siber memiliki karakteristik, antara lain: (1) mengandalkan interaksi dalam jaringan (network communication); (2) menipiskan perbedaan relasi real dan virtual (simulation); (3) menekankan pada pembuatan tampilan semenarik mungkin (artificial); (4) mengandalkan kemampuan berkomunikasi dan bersosialisasi dengan baik sehingga membuat orang betah berlama-lama (telepresence dan immersion). Hal ini berdampak pada manusia postmodern, yang identik dengan spesialisasi dan kedalaman. Dunia dan budaya siber inilah yang dapat dimanfaatkan untuk menjadi solusi pelaksanaan pilkada langsung di tengah pandemi Covid-19. Pilkada langsung yang menggunakan sistem pemilu elektronik.

Pemilu elektronik, selama ini sudah didiskusikan di Indonesia, namun masih terbatas pada tataran refleksi. Kunjungan kerja anggota DPR, untuk melihat sistem Pemilu elektronik di beberapa negara, eloknya dibarengi dengan aksi dan implementasi (bukan hanya refleksi). Pemilu elektronik dapat diartikan sebagai sistem pemilihan dengan memanfaatkan media elektronik, baik komputer ataupun jaringan internet (Hardjaloka, \& Megawati, 2011). Pemilu elektronik, tidak terbatas pada proses penyaluran hak suara, melainkan meliputi pula proses pendaftaran calon, verifikasi pemilih, kampanye, pemungutan suara, penghitungan suara, hingga pengumuman hasil. Pemilu elektronik paling tidak pernah dipraktikan di tingkat desa, seperti di kabupaten Jembrana (Hardjaloka \& Megawati), kabupaten Wonosobo, dan 2019 di Kabupaten Malang (Sobari, 2019), sehingga dapat kita jadikan percontohan dalam analisa.

Indonesia memerlukan persiapan dan penyesuaian konten, medium, dan nilai, untuk menerapkan pemilu elektronik. Transformasi fundamental ini harus dilakukan secara sinergis, oleh penyelenggara pemilu (KPU), pemerintah eksekutif, legislatif, dan yudikatif, serta terutama partai politik. Karena, dualisme dunia dan perubahan kultur masyarakat, berubah sangat dinamis dan begitu cepat. Konten pemilu hendaknya disesuaikan sesuai kultur masyarakat postmodern, yang mementingkan kedalaman isi dan materi. Demikian pula medium, yang terkait infrastruktur, hendaknya dipersiapkan secara matang dan memadai untuk memastikan keamanan dan kerahasiaan ketika proses pemilu dilakukan. Sedangkan untuk nilai, hendaknya tetap menghayati asas langsung, umum, bebas, rahasia, jujur dan adil.

Pemilu elektronik memiliki beberapa keunggulan (Hardjaloka \& Megawati, 2011), diantaranya: (1) Hemat biaya, baik dalam proses kampanye ataupun pemilihan; (2) sederhana dan efisien; (3) Waktu yang lebih fleksibel dan efektif; (4) Akurasi kalkulasi ketika penghitungan suara; (5) Meminimalisir terjadinya kecurangan dan tindak pidana Pemilu; (6) Lebih ramah lingkungan, karena mengurangi penggunaan kertas dan tinta kimia; dan terutama (7) mempermudah dan meningkatkan kenyamanan pemilih, terlebih ketika masa pandemi 
Jurnal Pembangunan Hukum Indonesia

Volume 2, Nomor 2, Tahun 2020
Program Studi Magister Ilmu Hukum

Fakultas Hukum Universitas Diponegoro seperti sekarang yang mengharuskan individu untuk menjaga jarak fisik/ physical distancing.

Selain kelebihan pada tataran teknis, pemilu elektronik juga mampu memikat ketertarikan anak muda yang cenderung apatis politik (Sobari, 2019). Syaratnya partai politik dan calon kepala daerah sebagai peserta kontestasi harus bertransformasi secara fundamental, menyajikan berbagai gagasan, ide, dan program yang jelas dan mendalam. Karena, sebagaimana telah disebutkan di atas, karakter manusia postmodern sekarang ini ialah terspesialisasi dan cenderung menyukai kedalaman. Dengan terpikatnya anak muda, maka tren ini akan memutus apatisme politik. Harapannya, angka golput menurun, anak muda bersiap menjadi pemimpin masa depan.

Namun kita perlu menyadari, sebagai sebuah sistem, pemilu elektronik juga memiliki kerentanan (Hardjaloka \& Megawati, 2011), yakni:

Keamanan dan kerahasiaan, yang mungkin memiliki celah elektronik ataupun diserang secara elektronik; (2) Logistik dan medium, yang mungkin belum tersedia secara merata; (3) Masalah operasional dan kesiapan sumber daya manusia, untuk mengoperasikan sistem elektronik yang ada; (4) Kesenjangan sosial yang masih terjadi, yang memungkinkan tidak menyentuh seluruh kalangan; (5) Kesiapan instrumen hukum terkait pemilihan elektronik, sekalipun Mahkamah Konstitusi pernah mengeluarkan Putusan MK No. 147/PUU-VII/2009 mengenai Pemilu elektronik; dan (6) kesiapan anggaran untuk membangun infrastruktur pemilu elektronik (mengingat fokus pengangaran Indonesia saat ini ditujukan untuk penanganan Covid-19).

Pola pilkada dengan pemilu elektronik mungkin dapat menjadi solusi. Terlebih DPR dan pemerintah selama ini telah berusaha merancangkan dan membangun sistem pemilu elektronik di Indonesia. Pandemi Covid-19 mungkin bisa menjadi katalisator, yang mempercepat perancangan dan pembangunan sistem pemilu elektronik tersebut. Kita perlu re-kreasi (re-create), membuat atau membangun kembali sebuah sistem yang memungkinkan pemilu, suksesi, dan demokrasi tetap berjalan. Terutama, ketika masa pandemi seperti ini, yang tidak memungkinkan kita berkumpul secara fisik. Maka kehadiran sistem pemilu elektronik, jadi suatu keniscayaan. Pandemi Covid-19 ini menyadarkan kita atau mungkin malah mengakselerasi persiapan Pemilu 4.0 di Indonesia.

Medium berupa infrastruktur fisik perlu diadakan, infrastruktur legal berupa hukum dan aturan terkait pemilu elektronik perlu didiskursuskan. Konten perlu dipersiapkan secara matang oleh penyelenggara (KPU) maupun peserta (Partai Politik), serta pemerintah (eksekutif, legislatif, dan yudikatif). Kelak, bila terjadi peristiwa luar biasa seperti pandemi ini, kita tidak gagap lagi dengan adanya Pemilu 4.0 dan demokrasi elektronik di era postmodern ini.

\section{Diskursus Hukum Pemilihan Kepala Daerah di tengah Pandemi Covid-19}

Perppu No. 2 Tahun 2020 yang dikeluarkan pemerintah dengan dukungan DPR, menunjukkan 
Jurnal Pembangunan Hukum Indonesia

Volume 2, Nomor 2, Tahun 2020
Program Studi Magister Ilmu Hukum

Fakultas Hukum Universitas Diponegoro
Indonesia tetap mempertahankan sistem pilkada secara langsung dengan cara konvensional. Namun keputusan ini tetap harus diapresiasi, karena adanya keinginan pemerintah untuk menjamin keberlangsungan hak konstitusional setiap warga negara. Meskipun begitu rencana pelaksanaan pilkada di bulan Desember sangat beresiko, karena hingga pertengahan bulan Mei ini angka penyebaran Covid-19 masih menunjukkan adanya peningkatan. Namun demi menjalankan pilkada konvensional tersebut, setidaknya ada dua aspek hak dalam HAM yang utama dan hendaknya menjadi perhatian khusus dalam penyelenggaraan pilkada serentak di tengah pandemi Covid-19, yaitu hak atas kesehatan dan hak atas politik (memilih dan/ atau dipilih).

Negara berkewajiban untuk melakukan pemenuhan HAM terhadap masyarakat, sehingga negara tidak boleh lalai dan mengabaikan hak atas kesehatan hanya demi berjalannya kontestasi politik dalam pilkada. Pengabaian terhadap hak atas kesehatan terlebih di tengah penyebaran pandemi Covid-19 akan berdampak pula pada hak lainnya terutama menyangkut hak atas hidup seseorang. Mengingat transmisi penyebaran Covid-19 yang terjadi begitu cepat dan meluas. Terlebih, orangorang dengan penyakit bawaan kronis, memiliki resiko kematian lebih tinggi bila terjangkit Covid-19 (Susilo et.al, 2020). Selain itu, hingga kini belum ada obat untuk menangkal Covid-19, para ilmuwan masih berlomba-lomba mencari vaksin yang tepat.

Berkaca pada Korea Selatan yang dianggap berhasil melaksanakan pemilu legislatif di tengah pandemi Covid-19, sangat memperhatikan aspek hak atas kesehatan. Korea Selatan melakukan penyesuaian secara ketat protokol kesehatan, sehingga patut dicontoh, namun dengan pertimbangan yang sangat matang dari berbagai aspek kehidupan masyarakat. Indonesia memerlukan kajian yang mendalam dan menyeluruh sebelum memutuskan benar-benar melaksanakan pilkada di tengah pandemi Covid-19. Korea Selatan dipilih menjadi percontohan, sebab ia lebih dekat secara kultural dengan Indonesia (Bangsa Timur), ketimbang Jerman dan Amerika (Bangsa Barat) atau Bangsa Afrika lainnya. KPU bersama Pemerintah dan DPR RI tentu harus membuat peraturan baru baik dalam Peraturan Komisi Pemilihan Umum (PKPU) maupun kebijakan pemerintah lainnya untuk menunjang penyelenggaraan pilkada di tengah pandemi Covid-19.

Sebagaimana kita ketahui, protokol kesehatan Covid-19 mengharuskan kita untuk physical distancing dan melarang kita untuk berkerumun, rajin mencuci tangan, menerapkan kesadaran dan etika ketika batuk, bersin, ataupun demam (Susilo et,al, 2020). Padahal, penyelenggaraan pilkada tentu akan berpotensi menimbulkan kerumunan. Maka, KPU sebagai penyelenggara hendaknya mengatur beberapa hal terkait protokol kesehatan dalam penyelenggaraan pilkada (Landman, \& Splendore, 2020), diantaranya: (1) Pembatasan jumlah masa ketika kampanye atau kegiatan-kegiatan politik lainnya yang menyangkut pilkada; (2) Mengatur pola dan mekanisme verifikasi dan pencocokan data 
pemilih oleh petugas (seperti yang telah dilaksanakan, dari yang dulunya mendatangi tiap rumah, sekarang dikoordinasi oleh Ketua RT) termasuk data dukungan calon perseorangan; (3) Pembatasan jumlah pemilih yang diperkenankan berada dalam Tempat Pemungutan Suara (TPS); (4) Menyediakan cairan pembersih tangan, alat pengukur suhu tubuh, dan bilik khusus untuk pemilih yang terindikasi demam di setiap TPS; (5) Mewajibkan pengukuran suhu tubuh kepada setiap pemilih atau petugas yang hendak memasuki TPS; (6) Mewajibkan petugas melakukan pemeriksaan kesehatan umum di fasilitas kesehatan tertentu yang ditunjuk untuk memastikan kesehatan dan kesiapan fisik sebelum bertugas; (7) Mewajibkan pemilih maupun petugas menggunakan alat pelindung diri berupa masker dan beberapa perangkat lainnya; dll; (8) memfasilitasi dan menjamin hak pilih warga yang berada di luar daerah pemilih, dengan opsi pengiriman surat suara melalui kantor pos layaknya pemilu bagi WNI di luar negeri.

Ketentuan mengenai 200andemic kesehatan itu hendaknya dinormakan dalam PKPU yang juga memuat sanksi-sanksi tertentu agar memiliki kekuatan berlaku mengikat dan efektif. Protokol kesehatan yang demikian ketat memang harus diterapkan ketika kita memilih melaksanakan pilkada secara langsung di TPS. Korea Selatan pun melaksanakan 200andemic kesehatan yang serupa. Konsekuensinya, memang hal ini akan menambah anggaran pengeluaran 200andem untuk perhelatan pilkada. Padahal, Perppu No. 2 Tahun 2020 secara substansi tak memberikan penambahan anggaran untuk perhelatan pilkada serentak 2020. Tentu ini menjadi masalah lain yang penting pula, karena saat ini anggaran pengeluaran 200andem difokuskan untuk penanganan dan penanggulangan 200andemic Covid-19.

Keberhasilan penyelenggaraan pilkada tersebut membutuhkan komitmen serius baik dari pemerintah maupun masyarakat. Pemerintah perlu berkerja keras dalam menangani Covid-19 dan diimbangi dengan kesadaran masyarakat atas aspek kesehatan dan hak konstitusionalnya. Artikel ini bermaksud untuk mendiskursuskan berbagai aturan guna memfasilitasi pilkada sesuai protokol kesehatan. Tujuannya adalah menjamin hak pilih serta hak kesehatan masyarakat. Artikel ini pun terbuka untuk segala pemikiran dan argumentasi lain. Kualitas pilkada bukan hanya soal ukuran keberhasilan prosedural, namun juga substansial yaitu terwujudnya hak konstitusional warga negara.

\section{SIMPULAN}

Covid-19 mengganggu penyelenggaraan pilkada di Indonesia. Kondisi menunjukkan, hingga akhir Mei 2020 jumlah kasus Covid-19 masih terus meningkat. Pilkada langsung terancam tidak dapat digelar, konsekuensi logisnya terjadi kekosongan jabatan kepala daerah. Untuk mencegah kekosongan tersebut, beberapa alternatif pola pengisian jabatan kepala daerah dapat menjadi solusi, diantaranya melalui penunjukkan penjabat sementara atau pelaksana tugas (PIt), Pilkada tidak langsung, dan 
Pilkada menggunakan sistem Pemilu elektronik. Herimanto., \& Winarno. (2010). Ilmu Sosial dan Masing-masing pola memiliki kelebihan dan kekuranganya, dengan argumentasi logis dan yuridis yang kuat dan dapat menjadi pertimbangan.

Namun, ketentuan Perppu No. 2 Tahun 2020 masih memilih cara Pilkada langsung secara konvensional. Patut diapresiasi bahwa pemerintah berupaya untuk mewujudkan hak konstitusional warga negara melalui penyelenggaran pilkada. Catatan pentingnya ialah, hak untuk memilih adalah HAM, demikian pula hak hidup dan hak atas kesehatan. Karena itu, Pemerintah wajib memastikan protokol kesehatan Covid-19 dijalankan secara ketat ketika pelaksanaan proses pilkada. Protokol kesehatan itu hendaknya dinormakan dalam PKPU dengan disertai sanksi agar memiliki kekuatan berlaku mengikat dan efektif. Penerapan protokol kesehatan ketika pilkada tentu berakibat pada kenaikan anggaran pengeluaran negara. Inilah harga yang harus dibayar untuk memastikan kesehatan warga negara dan keniscayaan sebuah demokrasi. Diskursus hukum tentang penyelenggaraan pilkada di tengah pandemi harus dilakukan, untuk memperbaharui dan menyesuaikan norma-norma sesuai normal baru yang tercipta karena pandemi.

\section{DAFTAR PUSTAKA}

\section{BUKU}

Asshiddiqie, J. (2014). Pengantar Ilmu Hukum Tata Negara, Ed.1, Cet. 6. Jakarta: Rajawali Pers.

Heim, M. (1993). The Metaphysics of Virtual reality. New York: Oxford University Press. 
Jurnal Pembangunan Hukum Indonesia

Volume 2, Nomor 2, Tahun 2020
Program Studi Magister IImu Hukum Fakultas Hukum Universitas Diponegoro
Serentak). J urnal Ilmu Pemerintahan, Vol. 1, (No.2), pp. 322-335.

Gennaro, Francesco Di., Pizzol, Damiano., Marotta, Claudia., Antunes, Mario., Racalbuto, Vincenzo., Veronese, Nicola., \& Smith, Lee. (2020). Coronavirus Diseases (COVID-19) Current Status and Future Perspectives: A Narrative Review. International Journal of Environmental Research and Public Health, Vol. 17, (No. 8), p.2690.

Hardjaloka, L. (2015). Studi Dinamika Mekanisme

Pilkada di Indonesia dan Perbandingan

Mekanisme Pilkada Negara Lainnya. Jurnal RechtsVinding, Vol. 4, (No.1), pp. 59-83.

Hardjaloka, Loura., \& Megawati, Varida. (2011). EVoting: Kebutuhan vs. Kesiapan (Menyongsong) E-Demokrasi. Jurnal Konstitusi, Vol. 8, (No. 4), pp. 579-604.

Hutapea, B. (2015). Dinamika Hukum Pemilihan Kepala Daerah di Indonesia. Jurnal RechtVindings, Vol. 4, (No.1), pp. 1-20.

Landman, Todd., \& Splendore, Luca Di Gennaro. (2020). Pandemic democracy: elections and COVID-19. J ournal of Risk Research, DOI: 10.1080/13669877.2020.1765003.

Leininger, Arndt., \& Schaub, Max. (2020). Voting at the dawn of a global pandemic. Paper in SocArXiv: University of Maryland, DOI: 10.31235/osf.io/a32r7.

Melfa, W. (2013). Penataan Hukum Menuju Hukum Ideal Dalam Pengaturan Pemilukada. Jurnal
Masalah-Masalah Hukum, Vol. 42, (No. 2), pp. 211-217.

Nugraha, Harry S. (2018). Gagasan Amandemen Ulang Undang-Undang Dasar Negara Republik Indonesia Tahun 1945. Jurnal Lex Renaissance, Vol. 3, (No. 1), pp. 61-85.

Respationo, H M Soerya. (2013). Pemilihan Kepala Daerah Dalam Demokrasi Electoral. Jurnal Masalah-Masalah Hukum, Vol. 42, (No. 3), pp. 356-361.

Santoso, Agus B. (2017). Eksistensi dan Problematika Calon Independen dalam Pilkada Ditinjau dari Perspektif Undang-Undang Nomor 8 Tahun 2015. J urnal Refleksi Hukum, Vol.1, (No. 2), pp. 147-160.

Saraswati, R. (2011). Calon Perseorangan: Pergeseran Paradigma Kekuasaan dalam Pemilukada. J urnal Masalah-Masalah Hukum, Vol. 40, (No.24), pp. 196-201.

Sobari, W. (2019). Memperluas Prespektif Kualitas Pemilihan Umum: Studi Kasus Praktik Semi-EVoting dalam Pemilihan Kepala Desa 2019 di Kabupaten Malang. J urnal Wacana Politik, Vol. 4, (No. 2), pp. 90-106.

Sodikin. (2015). Pemilihan Kepala Daerah dalam Konteks UUDN RI Tahun 1945. Jurnal RechtsVinding, Vol. 4, (No.1), pp. 43-58.

Susilo, Adityo., Rumende, C. Martin., Pitoyo, Ceva W., Santoso, Widayat Djoko., Yulianti, Mira., Herikurniawan., Sinto, Robert., Singh, Gurmeet., Nainggolan, Leonard., Nelwan, Erni J., Chen, Lie Kie., Widhani, Alvina., Wijaya, 
Edwin., Wicaksana, Bramantya., Maksum, Maradewi., Annisa, Firda., Jasirwan, Chyntia OM., \& Yunihastuti, Evy. (2020). Coronavirus Disease 2019: Tinjauan Literatur Terkini. Jurnal Penyakit Dalam Indonesia, Vol.7, (No.1), pp. 45-67.

Widyasari, Asita., Dewi, Reyke Anggia., \& Rengganis, Viera Mayasari Sri. (2019). Gerakan Politik Pendukung Kotak Kosong: Keterlibatan Civil Society dalam Pilkada Kabupaten Pati Tahun 2017. Jurnal PolGov, Vol 1, (No. 1), pp. 89-119.

Yang, Liu., \& Ren, Yang. (2020). Moral Obligation,

Public Leadership, and Collective Action for Epidemic Prevention and Control: Evidence from the Corona Virus Disease 2019 (COVID-

19) Emergency. International Journal of Environmental Research and Public Health, Vol.17, (No. 8), p.2731.

\section{PROSIDING \& ORASI ILMIAH}

Hidayat, A. (2010). Bernegara Itu Tidak Mudah (Dalam Perspektif Politik dan Hukum). Dalam Pidato Pengukuhan Guru Besar IImu Hukum. Semarang: Fakultas Hukum Universitas Diponegoro.

Danardono, D. (2016). Hukum sebagai Diskursus.

Dalam Konfrensi Politik, Hukum, dan Kekuasaan: Praktek Kuasa dan Komunikasi dalam Hukum dan Politik di Indonesia, Ke-II, 15 September 2016, Semarang: Fakultas Hukum dan Komunikasi Unika Soegijapranata.
Prasetyo, Banu., \& Trisyanti, Umi., (2018). Industri 4.0 dan Tantangan Perubahan Sosial. In Prosiding SEMATEKSOS 3: Strategi Pembangunan Nasional Menghadapi Revolusi Industri 4.0

\section{PERATURAN PERUNDANG-UNDANGAN}

Undang-Undang Dasar Negara Republik Indonesia Tahun 1945.

Undang-Undang Nomor 1 Tahun 1945 tentang Kedudukan Komite Nasional Daerah.

Undang-Undang Nomor 22 Tahun 1948 tentang

Penetapan Aturan-Aturan Pokok mengenai

Pemerintah Sendiri di Daerah-Daerah yang Berhak Mengatur dan Mengurus Rumah Tangganya Sendiri.

Undang-Undang Nomor 1 Tahun 1957 tentang Pokok-Pokok Pemerintah Daerah.

Undang-Undang Nomor 18 Tahun 1965 tentang Pokok-Pokok Pemerintah Daerah.

Undang-Undang Nomor 5 Tahun 1974 tentang

Pokok-Pokok Pemerintah di Daerah.

Undang-Undang Nomor 22 Tahun 1999 tentang Pemerintahan Daerah.

Undang-Undang Nomor 17 Tahun 2014 tentang Majelis Permusyawaratan Rakyat, Dewan Perwakilan Rakyat, Dewan Perwakilan Daerah, dan Dewan Perwakilan Rakyat Daerah.

Undang-Undang Nomor 22 Tahun 2014 tentang Pemilihan Gubernur, Bupati, dan Walikota. 
Jurnal Pembangunan Hukum Indonesia

Volume 2, Nomor 2, Tahun 2020
Program Studi Magister Ilmu Hukum Fakultas Hukum Universitas Diponegoro
Peraturan Pemerintah Pengganti Undang-Undang Nomor 1 Tahun 2014 tentang Pemilihan Gubernur, Bupati, dan Walikota.

Undang-Undang Nomor 8 Tahun 2015 tentang

Perubahan atas Undang-Undang Nomor 1

Tahun 2015 tentang Penetapan Peraturan

Pemerintah Pengganti Undang-Undang Nomor

1 Tahun 2014 tentang Pemilihan Gubernur,

Bupati, dan Walikota menjadi Undang-Undang.

Undang-Undang Nomor 10 Tahun 2016 tentang

Perubahan Kedua atas Undang-Undang

Nomor 1 Tahun 2015 tentang Penetapan

Peraturan Pemerintah Pengganti Undang-

Undang Nomor 1 Tahun 2014 tentang

Pemilihan Gubernur, Bupati, dan Walikota

menjadi Undang-Undang

Peraturan Pemerintah Pengganti Undang-Undang

Nomor 2 Tahun 2020 tentang Perubahan

Ketiga atas Undang-Undang Nomor 1 Tahun

2015 tentang Penetapan Peraturan

Pemerintah Pengganti Undang-Undang Nomor

1 Tahun 2014 tentang Pemilihan Gubernur,

Bupati, dan Walikota menjadi Undang-Undang.

Peraturan Pemerintah Nomor 49 Tahun 2008 tentang

Perubahan Ketiga atas Peraturan Pemerintah

Nomor 6 Tahun 2005 tentang Pemilihan,

Pengesahan Pengangkatan, dan

Pemberhentian Kepala Daerah dan Wakil

Kepala Daerah.

Putusan Mahkamah Konstitusi Nomor 147/PUV-

VII/2009.

\section{SUMBER ONLINE}

International Institute for Democracy and Electoral Assistance. (2020). Ikhtisar Global COVID-19: Dampak terhadap Pemilu. Retrieve from https://www.idea.int/sites/default/files/multimed ia_reports/13052020-overview-elections-andcovid-19-bahasa-indonesia.pdf.

Ramadhan, A. (2020). Ada 17.025 Kasus Covid-19 di Indonesia, Bertambah 529. Retrieve from kompas.com.

World Health Organization. (2020). WHO DirectorGeneral's opening remarks at the media briefing on COVID-19 - 11 March 2020. Retrieved from https://www.who.int/dg/speeches/detail/whodirector-general-s-opening-remarks-at-themedia-briefing-on-covid-19---11-march-2020 